\title{
Protocol
}

\section{Immunohistochemistry of Whole-Mount Mouse Embryos}

\author{
Alex Joyner and Nancy Wall
}

This protocol was adapted from "Techniques for Visualizing Gene Products, Cells, Tissues, and Organ Systems," Chapter 16, in Manipulating the Mouse Embryo, 3rd edition, by Andras Nagy, Marina Gertsenstein, Kristina Vintersten, and Richard Behringer. Cold Spring Harbor Laboratory Press, Cold Spring Harbor, NY, USA, 2003.

\section{INTRODUCTION}

The technique presented this protocol is ideal for obtaining an overall, three-dimensional picture of the distribution of an antigen in embryos from the prestreak stage to $\sim 10.5 \mathrm{dpc}$ (days post-coitum). The embryos are fixed and permeabilized so that antibodies can penetrate all of the tissues. However, antibodies will not penetrate the embryo completely if it is too large, and so it is better to dissect specific organs (e.g., brain, lungs, and gut) and process them separately.

\section{RELATED INFORMATION}

This protocol was adapted from Dent et al. (1989) and LeMotte et al. (1989). For a general discussion of immunohistochemistry; purification, storage, and use of antibodies; and appropriate controls for the specificity of the staining reaction, see Harlow and Lane (1999). The following related protocols are also available in CSH Protocols: Preparing Paraffin Tissue Sections for Immunostaining, Immunohistochemistry of Embryo Sections, Detection of Alkaline Phosphatase-Labeled Reagents, Binding Antibodies to Tissue Sections, Indirect Detection Using FluorochromeLabeled Reagents, Indirect Detection Using Horseradish-Peroxidase-Labeled Reagents.

\section{MATERIALS}

CAUTIONS AND RECIPES: Please see Appendices for appropriate handling of materials marked with $<!>$, and recipes for reagents marked with $<R>$.

\section{Reagents}

$<$ R $><$ ! $>$ BABB

Used to clear the embryos after staining and as a mounting medium to observe and photograph the stained embryos.

$<\mathrm{R}><$ ! $>$ DAB- $-\mathrm{NiCl}_{2}$ $<!>$ DMSO

Embryos of the desired stage

Eosin B (optional; see Step 17)

Ethanol (optional; see Step 17)

$<$ ! $>30 \%$ hydrogen peroxide $\left(\mathrm{H}_{2} \mathrm{O}_{2}\right)$

Store at $4^{\circ} \mathrm{C}$; the solution lasts $\sim 1$ mo at this temperature. 
$<$ ! Methanol

$<$ ! $>4 \%$ paraformaldehyde, prepared in PBS (see CSH Protocols article Fixation of Mouse Embryos and Tissues)

$<\mathrm{R}>$ PBS (phosphate buffered saline)

$<R>$ PBTX, prepared fresh before use

$<$ R $>$ PBSMT

The brand of skim milk used in the PBSMT is important. Carnation gives consistently good results, whereas other brands (e.g., Kroger) do not.

Primary antibody (e.g., an affinity-purified, polyclonal rabbit antiserum)

Secondary antibody (e.g., horseradish peroxidase [HRP]-coupled goat anti-rabbit lgG)

Serum (optional; see Step 1)

Wax (optional; see Step 17)

Xylene (optional; see Step 17)

\section{Equipment}

Depression slides and coverslips

Forceps, fine

Microcentrifuge tubes $(1.5 \mathrm{~mL})$

Micropipettes

Pasteur pipettes (optional; see Step 6.i)

Petri dishes (35 mm), glass and plastic

Photography equipment (see Step 16)

Rocking platform

Tubes $(15 \mathrm{~mL})$, screw-capped

\section{METHOD}

\section{Preparation and Fixation of Embryos}

1. Collect the embryos in PBS or tissue culture medium.

If the embryos are at the prestreak to early somite stages, it is advisable to add some serum ( 5\%) to reduce stickiness (this will cause a protein precipitate in the fixative, but do not be concerned).

2. Dissect away the extraembryonic membranes to facilitate penetration of the antibodies.

i. For early somite-stage mouse embryos (up to eight somites), use the tips of fine forceps to flatten the embryo by pushing the edges of the visceral yolk sac into the surface of a plastic Petri dish.

By "pinning out" the embryos in this way, they can be fixed flat and will remain extended after being detached from the dish. The extended shape allows better viewing of the somites and neural tube after staining.

ii. For older embryos (9.5-10.5 d), it is sometimes best to cut them in half sagitally before or after fixation.

This makes it easier to visualize and photograph staining of bilaterally symmetrical structures such as the cranial nerves, which otherwise appear as "double images."

3. Fix the embryos in freshly prepared methanol/DMSO $(4: 1)$ at $4{ }^{\circ} \mathrm{C}$ overnight. DMSO permeabilizes the tissues. See CSH Protocols article Handling Mouse Blastocysts for Fixation.

4. Transfer the embryos into freshly prepared methanol/DMSO/ $\mathrm{H}_{2} \mathrm{O}_{2}(4: 1: 1)$ at room temperature for 5-10 h.

This blocks endogenous peroxidase activity (e.g., in red blood cells).

5. Store the embryos (individually or in small groups) in $100 \%$ methanol at $-20^{\circ} \mathrm{C}$.

The embryos may be stored for at least several months and probably longer. 


\section{Immunohistochemistry}

6. Rehydrate the embryos at room temperature in microcentrifuge tubes as follows:

i. Add $1 \mathrm{~mL}$ of $50 \%$ methanol and incubate for $30 \mathrm{~min}$ with rocking. Remove the solution with a Pasteur pipette or micropipette.

ii. Add $1 \mathrm{~mL}$ of PBS and incubate for 30 min with rocking. Remove the PBS.

If embryos stick to the sides, siliconize the tubes.

iii. Add $1 \mathrm{~mL}$ of PBSMT and incubate for $1 \mathrm{~h}$ with rocking (do this twice, removing the solution after each wash).

Rocking is important to facilitate penetration of the antibody: Ensure that the solution is mixing well. However, the embryos are fragile once they are fixed, so do not rock them too hard.

7. Add $1 \mathrm{~mL}$ of primary antibody diluted in PBSMT. Incubate the embryos overnight at $4^{\circ} \mathrm{C}$ with rocking.

The correct dilution must be determined empirically, but 1:200 is a typical dilution. If the antibody is stable, this and all subsequent procedures can be performed at room temperature.

8. Wash the embryos in PBSMT with rocking as follows:

i. Wash once in $1 \mathrm{~mL}$ for $1 \mathrm{~h}$ at $4^{\circ} \mathrm{C}$. Transfer the embryos to a $15-\mathrm{mL}$ tube.

ii. Wash once with $10 \mathrm{~mL}$ for $1 \mathrm{~h}$ at $4^{\circ} \mathrm{C}$.

iii. Wash three times in $10 \mathrm{~mL}$ for $1 \mathrm{~h}$ at room temperature.

9. Transfer the embryos to microcentrifuge tubes. Add $1 \mathrm{~mL}$ of secondary antibody diluted 1:500 in PBSMT, and incubate them overnight at $4^{\circ} \mathrm{C}$ with rocking.

10. Wash the embryos again as in Step 8.

11. Rinse the embryos in $5 \mathrm{~mL}$ of PBTX, and then transfer them to microcentrifuge tubes. Wash them in $1 \mathrm{~mL}$ of PBTX with rocking for $20 \mathrm{~min}$.

12. Incubate the embryos in microcentrifuge tubes with $1 \mathrm{~mL}$ of $\mathrm{DAB}-\mathrm{NiCl}_{2}$ at room temperature for 30 min.

This allows full penetration of the substrate into the embryo.

13. Add $\mathrm{H}_{2} \mathrm{O}_{2}$ to a final concentration of $0.03 \%$ and rock until the color intensity in the embryos looks good (i.e., specific regions of staining are obvious and before background staining comes up; usually 2-10 $\mathrm{min}$ ).

If necessary, check color in the dissecting microscope. If the color reaction occurs too quickly, use a lower concentration of $\mathrm{H}_{2} \mathrm{O}_{2}$.

14. Post-fix the embryos in $4 \%$ paraformaldehyde.

Without post-fixation, the color of the stained embryos will fade under strong light, particularly under light used for photography.

15. Rinse the embryos at room temperature with rocking in the following series:

i. Quickly rinse in $1 \mathrm{~mL}$ of PBTX.

ii. Wash in $1 \mathrm{~mL}$ of PBTX for $30 \mathrm{~min}$.

iii. Wash in $1 \mathrm{~mL}$ of $50 \%$ methanol for $30 \mathrm{~min}$.

iv. Wash in $1 \mathrm{~mL}$ of $80 \%$ methanol for $30 \mathrm{~min}$.

v. Wash in $1 \mathrm{~mL}$ of $100 \%$ methanol for $30 \mathrm{~min}$.

If necessary, whole-mount embryos can be sectioned. If this is the case, proceed to Step 17.

16. Remove the methanol, add $500 \mu \mathrm{L}$ of $\mathrm{BABB}$, and rock for $10 \mathrm{~min}$. Make observations of the stained embryos in a glass Petri dish (do not use polystyrene dishes). For photography, place embryos in a depression slide with a coverslip on top. Use a tungsten color film without filters or a daylight color film with a blue filter. 
Although embryos can be stored in BABB in a dark place, it is advisable to obtain a photographic record as soon as possible.

\section{Preparation for Sectioning (Optional)}

17. Transfer the embryos from $100 \%$ methanol through the following series:

i. Wash twice in $100 \%$ ethanol for $1 \mathrm{~h}$ each.

ii. Wash twice in xylene for $1 \mathrm{~h}$.

iii. Wash once in xylene:wax (1:1) for $1 \mathrm{~h}$.

iv. Wash twice in wax for $1 \mathrm{~h}$ each.

v. Embed, section, and mount the embryos (for details, see CSH Protocols articles Embedding Mouse Embryos and Tissues in Wax and Sectioning Mouse Embryos). For counterstaining, use a light (30-45 sec) stain with eosin B.

\section{TROUBLESHOOTING}

Problem: Overall background staining in the tissues is high.

[Step 16]

Solution: It is extremely important to wash the embryos thoroughly to remove all unbound antibodies. If overall background staining in the tissues is high, even with thorough washing, reduce the concentration of the primary antibody. There will always be a problem with antibody trapping in cavities such as the ventricles of the brain.

\section{REFERENCES}

Dent, J.A., Polson, A.G., and Klymkowsky, M.W. 1989. A wholemount immunocytochemical analysis of the expression of the intermediate filament protein vimentin in Xenopus. Development 105: 61-74.

Harlow, E. and Lane, D. 1999. Using antibodies: A laboratory manual
Cold Spring Harbor Laboratory Press, Cold Spring Harbor, New York.

LeMotte, P.K., Kuroiwa, A., Fessler, L.I., and Gehring, W.J. 1989. The homeotic gene Sex Combs Reduced of Drosophila: Gene structure and embryonic expression EMBO / 8: 219-227. 


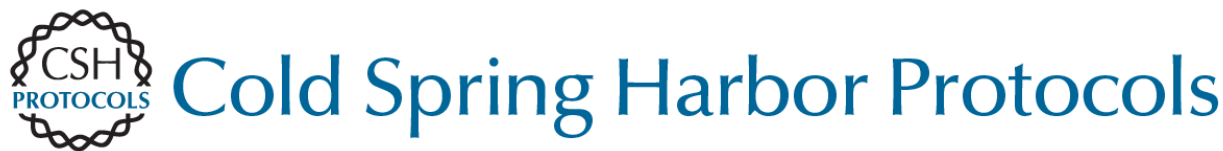

\section{Immunohistochemistry of Whole-Mount Mouse Embryos}

Alex Joyner and Nancy Wall

Cold Spring Harb Protoc; doi: 10.1101/pdb.prot4820

\begin{tabular}{|c|c|}
\hline $\begin{array}{r}\text { Email Alerting } \\
\text { Service }\end{array}$ & Receive free email alerts when new articles cite this article - click here. \\
\hline $\begin{array}{l}\text { Subject } \\
\text { Categories }\end{array}$ & $\begin{array}{l}\text { Browse articles on similar topics from Cold Spring Harbor Protocols. } \\
\text { Antibodies, general (289 articles) } \\
\text { Cell Biology, general (1382 articles) } \\
\text { Developmental Biology (728 articles) } \\
\text { Imaging Development (255 articles) } \\
\text { Immunohistochemistry (92 articles) } \\
\text { Laboratory Organisms, general (923 articles) } \\
\text { Molecular Biology, general (1293 articles) } \\
\text { Mouse (437 articles) } \\
\text { Protein ldentification and Analysis (202 articles) } \\
\text { Proteins and Proteomics, general (575 articles) } \\
\text { Visualization (524 articles) } \\
\text { Visualization of Proteins (107 articles) } \\
\text { Visualization, general (369 articles) }\end{array}$ \\
\hline
\end{tabular}

